\title{
Appraisal of Issues Influencing Soil-Steps Application for Sustainable Farmland Management in High-Potential District, Ethiopia
}

\author{
Mehretie Belay \\ Department of Geography \& Environmental Studies, Bahir-Dar University, Ethiopia \\ E-mail: belaymehrete@yahoo.com
}

Received: June 18, 2018 Accepted: July 10, 2018 Published: August 21, 2018

doi:10.5296/emsd.v7i3.13535 URL: https://doi.org/10.5296/emsd.v7i3.13535

\begin{abstract}
Soil damage by moving water is a somber predicament on farmlands in highland Ethiopia. Sizeable number of trial in farmland preservation has been executed to handle the crisis during the last tens of years. However, the attempts have not been vibrant to trim-down the danger to an attractive extent. This paper evaluates factors contributing to application of soil-steps (bunds) as sustainable farmland management technology (SFLMT) by smallholder farmers in one of the high-potential districts of northwest Ethiopia named Dangila Woreda (District). Mixed method triangulation designs involving concurrent acquisition and interpretation of quantitative and qualitative data were used in the study. Data were acquired from randomly chosen 201 farming households during the harvest seasons of 2011 and 2012. Ordered questionnaire, participatory field observation, key informant interview and focus group discussion were mechanisms employed during the data acquisition. Descriptive statistics (means, standard deviations and percentiles), Chi-square test, t-test and the binary logistic regression model were used to analyze the quantitative data. The qualitative information was textually narrated to augment the quantitative results. Findings of the investigation confirm that age of the household head, the number of household members, slope of the farmland, the size of the farmland held, households' participation in indigenous labour-sharing activities and the number of farm tools owned were significantly increasing the building of soil-steps as SFLMT in the study district. Involvement in off-farm activities and pest invasions were considerably hindering farmers from building soil-steps on their farmlands. The results in general indicated that households' access to livelihood assets are key promoters for farmers' implementation of soil-steps on their farmlands. Local resource preservation and improvement trials should thus ponder on convalescing farmers' material endowments to improve their capability to use soil-steps as SFLMT in their farming
\end{abstract}


activities.

Keywords: Farmland management, Sustainable technology, Soil-steps building, Ethiopia

\section{Introduction}

Farmland is a key asset in an agricultural society. It is the prime resource for living in rural settings of the world (Rahman \& Manprasert, 2006; Kastner \& Nonhebel, 2010). Farmland in Ethiopia is the pillar of households' socio-economy and government politics (Adenew \& Abdi, 2005). But, the size of cultivable land per family unit has been continuously diminishing and getting less productive in latest decades due to abuse and maltreatment (Pender \& Gebremedhin, 2007). Mounting demographic pressure in vast areas of the highlands $(>1,500 \mathrm{~m}$ a.s.l.) forced farmers to stop using the traditional land resting actions to renovate soil fertility (Rahmato, 2004). In immense areas of the highlands, resource exhaustion is more somber compared to other world regions and nearly all the mountain terraces have vanished their inborn productive capacities (Tesfay, 2006). Resource collapse, low farming output and escalating poverty have thus remained to be grave headaches in the Ethiopian highlands (Pender \& Gebremedhin, 2007). Population stress, inapt land use, land tenure insecurity and lack of attentiveness about the crisis by the farmers are ascribed as causes and factors for the aforementioned harms in the said highlands (Hurni et al., 2005).

Sizeable endeavours have been undertaken to lessen the resource fatigue in the country throughout the recent past decades (Amsalu \& de Graaff, 2007; Kassie et al., 2007, 2010). However, attainments in renovating damaged lands and halting the processes of soil removal have not been to an advantageous extent and shift to be afterward "motives" as recognized by studies in various localities of the country (Hurni et al., 2005). Kassie et al. (2010) noted that natural resource management packages to endorse smallholder soil and water management (SWM) endeavors are absent except for promoting the use of marketable inputs. The centre of attention of the contemporary rule in this context is so feeble, restricted to temporary erection of bunds using obligatory "One-into-five" free individual labour (Mosseye \& Belay, 2018) through plain blanket frameworks (Kassie et al., 2010).

Some researchers argue that farmers in Ethiopia are apathetic to install long-lasting and sustainable farmland management technologies (SFLMTs) because of their strong inclination to harvest short-range benefits in the milieu of the government ownership of land (Sutcliffe, 1995; Gebremedhin \& Swinton, 2003). Technologies with long-range benefits are often discarded by the farmers and in some cases even previously installed physical structures were soon ruined (Sutcliffe, 1995; Shiferaw \& Holden, 1998; Tadesse \& Belay, 2004). For instance, Tadesse \& Belay (2004) signified that out of 80 interviewed farmers in the Gununo area, southern Ethiopia, $41.3 \%$ ruined in part and 36.3\% utterly formerly installed SWM structures.

Many authors note that a number of factors manipulate farmers' use of SWM technologies (Shiferaw \& Holden, 1998; Bekele \& Drake, 2003; Gebremedhin \& Swinton, 2003; Tadesse \& Belay, 2004; Amsalu \& de Graaff, 2007; Anley et al., 2007; Kammer, 2014; Teshome et al., 2014; Wolka \& Negash, 2014; Birhanu, 2016). For instance, Shiferaw \& Holden (1998) suggested that farmers' insights of soil attrition and fresh technology use, disclosure to latest 
practices, ownership of per capita cultivable land, parcel area, land slope and usefulness of applied technology notably and positively influence adoption of SWM structures in central Ethiopia. They specified also that age, household number and farm position appreciably, but negatively manipulate retention of SWM structures.

Bekele \& Drake (2003) signified that farmers' SWM decisions were positively influenced by insight of soil attrition, affluence position of the households and beginning financial help in southeastern Ethiopia. In their work, household size was observed to negatively correlate with application of SWM technologies. Gebremedhin \& Swinton (2003) also revealed that physical characteristics, household capacities to invest and socio-institutional factors were important in manipulating farmers' application of stone-barriers in northern Ethiopia. They suggested that farmers desire to erect stone-barriers on middle and lower sloping-lands. Their study further signified that labour and ownership of larger farmlands favoured use of the stone-embankments. Farmland distance from the villages and markets have been harmfully manipulating application of stone-embankments in northern Ethiopia according to these writers.

Tadesse \& Belay (2004) uncovered that the size of working persons in the household, farm position and insight on soil attrition and farmland dimension had confidently and appreciably manipulated farmers' application of soil-steps and fanya juи terraces (fanya juи are SWM practices involving the throwing of soils uphill) in the Gununo area, southern Ethiopia. A paper by Amsalu \& de Graaff (2007) in the central highlands of Ethiopia remarked as well that age, farmland slope and farmland size significantly raised technology application practices. In western Ethiopia, Anley et al. (2007) also noted that education, farmland slope and farmland size significantly amplified application of SWM structures. Farmland distance from the homesteads, expert supervision and farmers' age were depressingly upsetting the technology application practices in the mentioned area.

Kammer (2014) remarked that wakefulness on the technologies and supports during farming times manipulate farmers' SWM investment choices in the Magersa and Konso communities of southern Ethiopia.Physical efficiency, financial competence and social adequacy of SWM structures are also suggested to have control of farmers' choices to apply SWM technologies in northwest Ethiopia (Teshome et al., 2014). Wolka \& Negash (2014) also noted that farmland size and workability of SWM structures appreciably correlated with application of sustainable technologies in Bokole sub-watershed, southern Ethiopia. These authors added that distance to a nearby market significantly decreased SWM use in another sub-watershed named Toni.

Birhanu (2016) reported that sex, age, farmland slope; plan to continue farming activities, training and extension service appreciably improved adoption of SWM measures in northern Ethiopia. The same author indicated that farmland size, off-farm job and credit availability unhelpfully influenced farmers' application decisions of the measures.

Thus, farmers' judgments on utilizing manifold SWM technologies have been evaluated by diverse earlier studies in different parts of Ethiopia and also in other parts of the world. Such studies enabled identification of the constraints encountered during application of the specific 
technologies.

Soil-steps ${ }^{1}$ are among such technologies used by many farmers in Ethiopia and the study area. They are embankments made of soil mounds across the sloping lines of farmlands to improve water retention capacity of soils and divert/control water runoff resulted from torrential rainfall. They can be built by digging the soil with a spade or else by ploughing using a pair of oxen (Belay, 2013). In some localities, soil-steps are often installed in association with fanya juи terraces in the micro-watersheds to enhance soil water retention behavior through obstruction of up-coming flood. Both of these technologies are installed in a similar fashion by excavating soil along the contour using human labour. But, the soil dug in the case of fanya juu bunds is dropped upslope against what is happening during construction of soil-steps where the excavated material is placed downslope. With respect to this, fanya jии construction requires more labour than the soil-embankment which can possibly be built with the help of oxen-dragged ploughs. Nevertheless, fanya juи terraces are preferred by farmers to soil-steps in many locations because their ditches effectively trap up-coming water and turn into 'bench-terraces' in short time periods. They are essential SWM technologies in arid and semi-arid environments where cultivation is constrained by scarce soil moisture. As the downhill placed channels cannot be easily crossed and grazed by livestock; fanya juu terraces are not easily broken by moving animals compared to the soil-steps. Soil-steps are easily crossed and grazed by livestock and are more prone to breakage (Teshome et al., 2014).

Soil and fanya juи bunds can store water in the depressions during rainstorms and sometimes affected by the problem of waterlodging and silt deposition. Both are stabilized by planting trees, shrubs and grasses on the risers. The plants grown in this way may eventually serve for fuel or animal feed purposes. Maintenance is retained through improving the structures by means of reforming broken parts and increasing the quality of the structures and vegetative supports. Nevertheless, maintenance of both structures is not an easy task, particularly the soil-steps (Teshome et al., 2014). Both soil-steps and fanya juu terraces are preferred farm management technologies in areas where stones are scarce. In areas of abundant stone-cover, stone-terraces are preferred to soil or fanya juu bunds because they are durable and cannot be simply injured by walking animals (Desta et al., 2005).

Unlike soil and fanya juи bunds, stone-terraces are usually erected in areas rich with surface stones. They are commonly practiced indigenous conservation structures in northern Ethiopia (Gebremedhine \& Swinton, 2003). No more digging of soil is required during construction of stone-terraces because they are built from piling of stones found in the vicinity. They do not require recurrent safeguarding as is common in soil and fanya juu bunds, but, call for more labour throughout creation. They are resilient and strong; not effortlessly injured by flood water and moving animals like the soil and fanya juu bunds. But, they are not friendly with farming actions using oxen and refuge pests that can inflict harm on crops (Vancampenhout $e t$ $a l ., 2006)$. Stone-terraces can rapidly drain-out extra water via the joining parts of the stones,

${ }^{1}$ Soil-steps are terraces /bunds made of soil-piles or mounds to control soil loss by running water 
and hence, waterlodging is not serious trouble compared to soil and fanya juu bunds (Gebremedhine \& Swinton, 2003; Teshome et al., 2014).

In Ethiopia, the erection of soil-steps have been encouraged in SWM interventions (from 1975-1991) in combination with 'stone-terraces' and are also endorsed by the existing government (Belay \& Bewket, 2012a \& b). It has also been checked in an exploratory survey that soil-steps are widely practiced on farm fields in the study district. But, Belay \& Bewket (2012a \& b) indicated that only $32 \%$ of the farms in the study district were covered with soil-steps. This implies that soil-steps are not implemented on all the farmlands and by all of the farmers of the study area. The factors that contribute to this are not also studied. The major rationale for selecting Dangila District as a site for this study is absence of a similar previous research, on SFLMTs, mainly on soil-steps use, as far as known to this author. Despite its high-rainfall and favourable agricultural setting, Dangila District is rapidly losing its agricultural potential due to intensified land degradation initiated by dense population. Soil fertility depletion, gully expansion, declining water potential and poverty are major problems in the area (Negash, 2006; Belay \& Bewket, 2012a, b). The inclusion of Dangila District in the 'high-potential'- high-yielding crop-zone following the regional agroecology classification (ALZR, 2007), research attention has diverted away from the district; and hence, there are no major recent studies on SFLMTs, so a knowledge gap for this study to deal with.

This study intends to evaluate issues controlling farmers' actions of building soil-steps (i.e. construction of soil embankments on farmers' fields) as SFLMT in a high-potential district named Dangila Woreda, in the north-western highlands of Ethiopia. It seeks to answer the question: What demographic, biophysical and socioeconomic factors control application of soil-steps in study district? Recognizing what demographic, biophysical and socioeconomic factors control application of soil-steps is helpful to deal with the challenges of sustainable farmland management use in the mentioned district and other comparable settings.

\section{The Study Area and Methods}

\subsection{The Study District}

The study district (Dangila Woreda) is situated within $11^{0} 04^{\prime} 48^{\prime \prime}-11^{0} 24^{\prime} 36$ 'N latitudes and $36^{0} 34^{\prime} 48^{\prime \prime}-37^{0} 00$ ' $37^{\prime \prime}$ E longitudes (Figure 1); about $480 \mathrm{kms}$ to the northwest of Addis Ababa, the capital city of Ethiopia. It is $918.4 \mathrm{~km}^{2}$ in area (CSA, 2010). The general elevation in Dangila District traverses between 1,500 and 2,400 m a.s.l. (Belay, 2013). Volcanic materials mainly belonging to the quaternary and tertiary formations overlying the older geological formation of the ancient eras dominate the area (e.g. see Arndt \& Menzies, 2005). Lithosols, Nitosols, Vertisols, Luvisols, Gleysols, Cambisols and rocky surfaces are major soil covers in the district (Belay, 2013). 


\section{Macrothink}

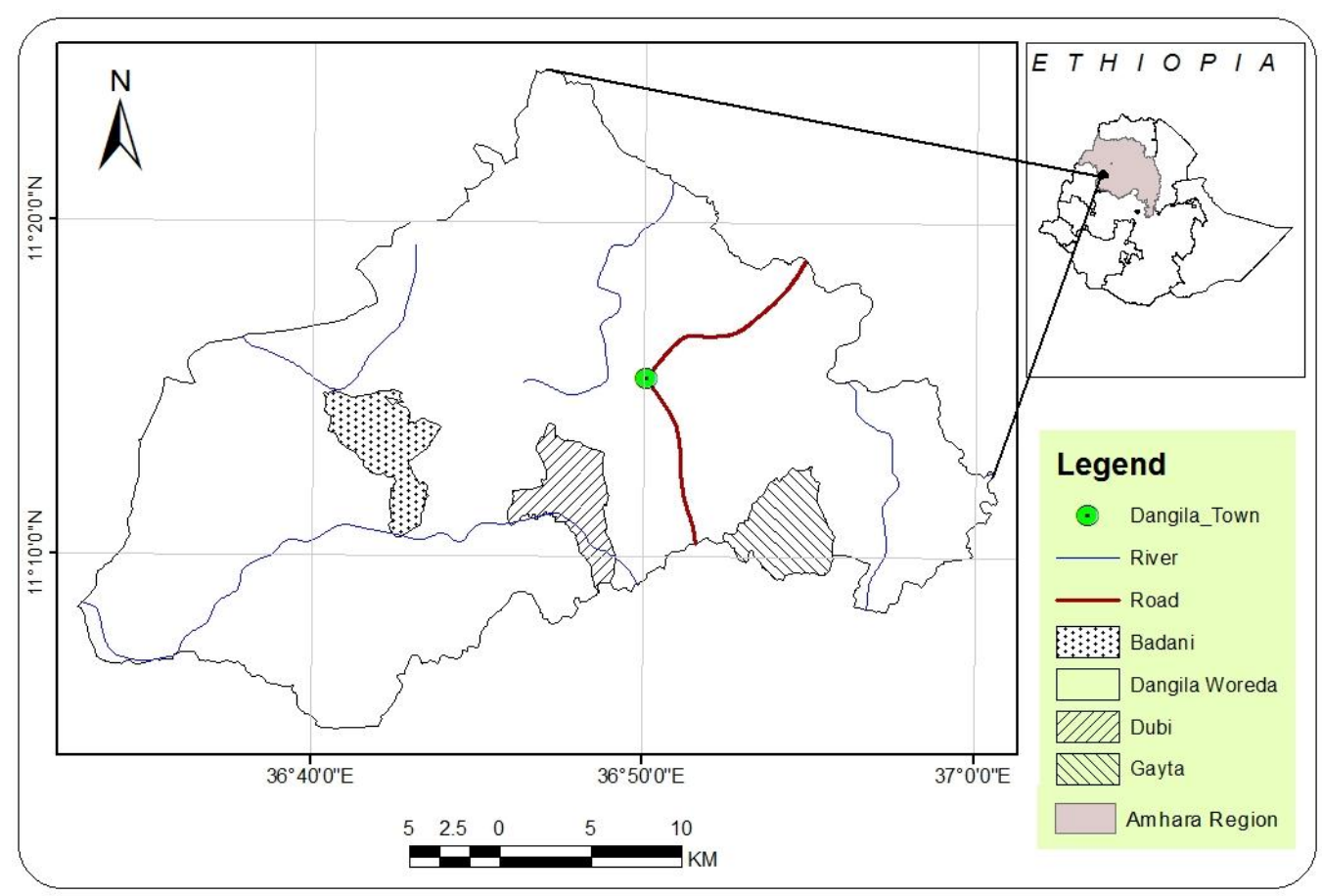

Figure 1. Location map of the study area (Belay \& Bewket, 2013a)

Copious watercourses [rivers including Awsi, Ghizani, Quashini, Guder, Gilgel-Abay (the little Blue-Nile) and its tributaries] and several streams flow across the district (Negash, 2006). The Tiski waterfalls form striking land features in the district. Weina-Dega (a moist sub-tropical agroecology) dominates the broad climate of the district. Temperature and precipitation records (at $11^{0} 16^{\prime} 00^{\prime \prime} \mathrm{N} \& 36^{0} 50^{\prime} 00^{\prime \prime} \mathrm{E}$ ) accessed from the Ethiopian Meteorological Agency (EMA, 2010) signify that the yearly average temperature is $17^{\circ} \mathrm{C}$ and the total annual rainfall is $1578 \mathrm{~mm}$. Months from May to October experience the highest proportion (93\%) of the total rainfall with highest values stirring in August, July and June, respectively. The driest month in the area is January (with $2 \mathrm{~mm}$ rainfall) and the wettest is August with about $358 \mathrm{~mm}$ rainfall (Belay \& Bewket, 2013b). Except the plantation forests found at both the right and left sides of the Addis Ababa-Bahir-Dar asphalt road and on the ridges of Senbu, Gundri, Gayta, Gishen, and Agew-Mender, no intact natural forests are found in the district. Remnant forests with broad Eucalyptus plantations are observed on remote villages such as Muksi, Jibana, Chiwaghi, Dimsa, Washa, Alefa-Kacha and on the ridges of Kansen.

The 2017 mid-year total population in Dangila District is 199,197 of which 98,282 are females and 100,814 males (CSA, 2013). Using this data, the crude density of population for the district in the mentioned period calculated 216.9 persons per $\mathrm{km}^{2}$ giving a much larger figure compared to the national average density of 85.4 persons per $\mathrm{km}^{2}$ computed for the same period. The number of people residing in towns is accounting for $23.6 \%$ of the total district population. This figure is also much larger than the national average which is $20.23 \%$.

Mixed agriculture is the main stay of over $80 \%$ of the population in Dangila District. Farmland, livestock and family labour constitute the most important livelihood assets in the 
district. Crop cultivation, livestock keeping - for milk, farm power and cash, petty-trading, charcoal and wood selling, participation in daily labour and in off-farm business are among the main livelihood strategies of the people in the district. Growing of potato (Solanum tuberosum), maize (Zea mays) and vegetables using irrigation around the homesteads is a common practice in most villages (see Belay \& Bewket, 2013b, 2015; Belay et al., 2017).

\subsection{Data and Methods}

Mixed method research designs were used in this study to retain the concurrent acquisition and analysis of quantitative and qualitative information. Based on this approach, both numerical and qualitative data were gathered from 201 randomly chosen farm households, three focus groups (containing six members each), nine key informants and from observation and participatory field tours in three rural villages in the north-western highlands of Ethiopia. A multi-stage sampling approach was employed to determine the households studied. Primarily, three Rural Keble Administrations (RKAs: local government units) named: Badani, Dubi and Gayta (Figure 1) were purposely picked so as to use as specific focus areas. The motives behind their choices were closeness and ease of access to the district town (Dangila) and presence of all-weather road-network and four-wheel transport. The 201 sample size for the study was determined with consideration of funds and time available for the study and homogeneity of the studied population. Then, the records of the households' were taken from the respective village administration offices and stratified by RKA. From the stratified records, a total of 201 households ( 31 headed by women and 170 headed by men) were scientifically chosen from a total of 2013 households in a proportionate way. Additional 27 household heads were also chosen for focus group discussion (FGD) and key informant interview, owing to their outstanding knowledge of the area.

For data acquisition, well-structured questions focusing on farmers' household demography, resource endowment, SWM technology application and perception were designed and translated into the native language (Amharic). Before gathering the data, the designed questions were pre-tested for fitness and validity. Based on the pre-test feedback, relevant improvements were made on ambiguous questions and filled by the sampled households during the harvest season of 2011/ 2012 through face-to-face interviews. Three university graduated assistants and the researcher performed the face-to-face interviews with the assistance of Development Agents (DAs). The numerical data developed from the ordered questionnaires were simultaneously enriched by FGDs, key informant interviews and participatory field observations.

The data generated through different approaches are concurrently interpreted using quantitative and qualitative data analysis methods. T-test, Chi-square test and binary logistic regression model were used in the examination of the data with the support of information from FGDs, key informant interviews and field observations.

T-test and Chi-square test were correspondingly used to primarily check the differences and level of associations of variables within the groups and categories. The t-test was specifically used to appreciate the mean differences in age, education level, and number of family members, farmland size and farmland distance from homesteads, rate of recurrence of 


\section{Macrothink}

meeting with DAs and the number of farm tools owned between soil-steps builder and non-builder household groups. The Chi-square test was used to analyze the relationship between categorical variables such as the gender of the household heads, farmers' involvement in off-farm business and indigenous labour associations and their alleged farmland slope, tenure insecurity, waterlodging and pest infestation problems. The issues showing meaningful variations/links in the t-test and Chi-square test were then further integrated in the binary logistic model.

The binary logistic regression model was engaged to evaluate the issues manipulating farmers' soil-step erection choices. It is chosen for suiting to manipulate dummy and categorical factors that are not fitting linear regression models (Chan, 2004). Soil-step building was the criterion factor defined as a dummy: ' 1 ' categorized as building soil-steps and ' 0 ' considered as not-building soil-steps. Households were classified as soil-step builders and non-builders. Soil-step builders are households who started constructing soil-steps on their farm fields during the past three years (2009-2011); whilst non-builders were those who have not started building the structures during the mentioned years.

The numerical results of the analysis were triangulated with FGD, key informant interview and field observation data. Data preparation and analysis practices were managed using Microsoft Excel and the Statistical Package for Social Scientists (SPSS Version 20). The fitness of the data used in the study to the binary logistic model was evaluated by using the Pearson's Chi-square $\left(\chi^{2}\right)$, the Hosmer and Lemeshow's test of goodness-of-fit (Hosmer \& Lemeshow, 1989) and the taxonomic table of the studied cases. The extent of linear association among the predictor factors were also checked using a correlation matrix.

\subsection{Choice of Predictor Issues/Factors}

Issues controlling implementation of SFLMTs and practices like that of soil-steps were considered numerous and multidimensional. For this case, 14 issues anticipated manipulating farmers' soil-step application decisions were identified via assessment of previous SWM literatures. The portrayals, assumptions and sources of the 14 issues considered are explained in Table 1 under three major subheadings. 
Table 1. Description of predictor issues used in the analysis, assumptions and sources

\begin{tabular}{|c|c|c|}
\hline Influential issues & Postulates & Supporting Literature \\
\hline \multicolumn{3}{|l|}{ Household demographic issues } \\
\hline $\begin{array}{l}\text { Gender of the household head ( } 1 \\
\text { if male, } 0 \text { otherwise) }\end{array}$ & $\begin{array}{l}\text { Male-headed households build more } \\
\text { soil-steps than female headed } \\
\text { households }\end{array}$ & $\begin{array}{l}\text { Holden et al. [2001]; Pender \& } \\
\text { Gebremedhine [2007]. }\end{array}$ \\
\hline Age of household head (in years) & Expected to have a mixed effect $( \pm)$ & Amsalu \& de Graaff [2007]. \\
\hline $\begin{array}{l}\text { Education of the household head } \\
\text { (school attended years) }\end{array}$ & $\begin{array}{l}\text { More school exposure increases } \\
\text { soil-steps building behaviour }\end{array}$ & $\begin{array}{l}\text { Lapar \& Pandey [1999]; Amsalu \& } \\
\text { de Graaff [2007]. }\end{array}$ \\
\hline Number of household members & $\begin{array}{l}\text { Soil-steps building increases with } \\
\text { increased number of household } \\
\text { members }\end{array}$ & Tadesse \& Belay [2004]. \\
\hline \multicolumn{3}{|l|}{ Household resource endowments } \\
\hline Farmland size (ha) & $\begin{array}{l}\text { Ownership of large farmlands } \\
\text { encourage soil-step building interest }\end{array}$ & $\begin{array}{l}\text { Bekele \& Drake [2003]; } \\
\text { Gebremedhin \& Swinton [2003]; } \\
\text { Tadesse \& Belay [2004]. }\end{array}$ \\
\hline $\begin{array}{l}\text { Farmland slope (1 if steep, } 0 \\
\text { otherwise) }\end{array}$ & $\begin{array}{l}\text { Steep slope farmland position pushes } \\
\text { farmers to build more soil-steps }\end{array}$ & $\begin{array}{l}\text { Shiferaw \& Holden [1998]; Anley } \\
\text { et al. [2007]; Medhin \& Köhlin } \\
\text { [2009]. }\end{array}$ \\
\hline $\begin{array}{l}\text { Problem of waterlodging } \\
\text { (1 if yes, } 0 \text { otherwise })\end{array}$ & $\begin{array}{l}\text { Waterlodging problems discourage } \\
\text { farmers' soil-step building interests }\end{array}$ & $\begin{array}{l}\text { Kassie et al. [2007, 2010]; Gebre \& } \\
\text { Woldemariam [2013]. }\end{array}$ \\
\hline $\begin{array}{l}\text { Problem of pest infestation } \\
\text { ( } 1 \text { if yes, } 0 \text { otherwise) }\end{array}$ & $\begin{array}{l}\text { The problem of pest infestation } \\
\text { reduces soil-step building } \\
\text { interventions }\end{array}$ & $\begin{array}{l}\text { Vancampenhout et al. [2006]; } \\
\text { Kassie et al. [2007]; Gebre \& } \\
\text { Woldemariam [2013]. }\end{array}$ \\
\hline $\begin{array}{l}\text { Round-trip of farmland } \\
\text { distance from home (in kms) }\end{array}$ & $\begin{array}{l}\text { Long distance from homesteads to } \\
\text { farms reduce farmers' soil-steps } \\
\text { building actions }\end{array}$ & $\begin{array}{l}\text { Gebremedhine \& Swinton } \\
\text { [2003]; Anley et al. [2007]. }\end{array}$ \\
\hline \multicolumn{3}{|l|}{ Household socio-economic issues } \\
\hline $\begin{array}{l}\text { Partaking in local labour groups } \\
\text { (1 if yes, } 0 \text { otherwise) }\end{array}$ & $\begin{array}{l}\text { Participation in local labour groups } \\
\text { increases soil-steps construction }\end{array}$ & $\begin{array}{l}\text { Lapar \& Pandey [1999]; } \\
\text { Mbaga-Semgalawe \& Folmer } \\
\text { [2000]; Mossie \& Belay [2018]. }\end{array}$ \\
\hline $\begin{array}{l}\text { Performing off-farm work } \\
\text { ( } 1 \text { if yes, } 0 \text { otherwise) }\end{array}$ & $\begin{array}{l}\text { Performing off-farm work reduce } \\
\text { soil-steps construction }\end{array}$ & $\begin{array}{l}\text { Shiferaw \& Holden [1998]; } \\
\text { Amsalu \& deGraaff [2007]; Belay } \\
\& \text { Bewket [2013a]. }\end{array}$ \\
\hline $\begin{array}{l}\text { Farmers' meeting days } \\
\text { with the DAs in a year }\end{array}$ & $\begin{array}{l}\text { Frequent meeting with DAs } \\
\text { promotes farmers' soil-steps building } \\
\text { activities }\end{array}$ & $\begin{array}{l}\text { Gebremedhine \& Swinton [2003]; } \\
\text { Amsalu \& de Graaff [2007]; } \\
\text { Anley et al. [2007]. }\end{array}$ \\
\hline $\begin{array}{l}\text { Feeling of tenure insecurity } \\
\text { ( } 1 \text { if yes, } 0 \text { otherwise) }\end{array}$ & $\begin{array}{l}\text { The feeling of tenure insecurity } \\
\text { discourage soil-steps building } \\
\text { practices }\end{array}$ & $\begin{array}{l}\text { Gebremedhine \& Swinton [2003]; } \\
\text { Rahmato [2004]; Belay et al. } \\
\text { [2017]. }\end{array}$ \\
\hline Number of farm tools owned & Expected to have positive influence & Belay \& Bewket [2013a] \\
\hline
\end{tabular}




\section{Results and Discussion}

\subsection{Descriptive Results}

\subsubsection{Household Demographic Issues}

Descriptive data offered in Tables 2 and 3 specify that there are important variations between soil-step builders and non-builders in many of the demographic factors. Soil-step builder households emerged having higher mean ages (46 years vs to 38 years for non-builders) and higher numbers of family members ( 7 vs to 5 for non-builders); and the variation was statistically significant for both $(\mathrm{P}<0.01$, Table 2$)$. Likewise, the share of women-headed households in the soil-steps builder group is considerably inferior to the non-soil-steps-builder groups, entailing that women-headed households have lesser possibilities of erecting soil-steps $\left(\chi^{2}=7.47, \mathrm{P}<0.05\right.$, Table 3$)$. Nevertheless, no significant variation was observed between soil-step builders $\&$ non-builder households with regard to education level of household heads (Table 2).

Table 2.T-test comparison of soil-step builder and non-builder households

\begin{tabular}{|l|c|c|c|c|c|}
\hline \multirow{2}{*}{ Factors } & \multicolumn{2}{|c|}{$\begin{array}{c}\text { Builders } \\
(\mathrm{n}=44)\end{array}$} & \multicolumn{2}{c|}{$\begin{array}{c}\text { Non-builders } \\
(\mathrm{n}=157)\end{array}$} & \multirow{2}{*}{ T-test } \\
\cline { 2 - 5 } & Mean & SD & Mean & SD & \\
\hline Age in years & 45.80 & 12.66 & 37.88 & 13.42 & $3.50^{\mathrm{a}}$ \\
\hline Education (year attended) & 1.14 & 2.09 & 1.34 & 2.60 & -.473 \\
\hline Number of family members & 7.09 & 2.13 & 5.19 & 1.94 & $5.62^{\mathrm{a}}$ \\
\hline Size of farmland owned (ha) & 1.92 & 0.71 & 1.28 & 0.59 & $6.04^{\mathrm{a}}$ \\
\hline Farm distance from home (km) & 1.38 & 1.14 & 1.30 & 0.98 & 0.44 \\
\hline Meeting with DAs (days yr $\left.{ }^{-1}\right)$ & 1.89 & 0.95 & 0.73 & 0.49 & $11.03^{\mathrm{a}}$ \\
\hline $\mathrm{N}^{0}$ of farm equipments owned & 1.16 & 0.57 & 0.46 & 0.54 & $7.55^{\mathrm{a}}$ \\
\hline
\end{tabular}

${ }^{\text {a }}$ Significance at $\leq 0.01$ level.

\subsubsection{Resource Endowment and Biophysical Issues}

Soil-step builder households had larger farmland holdings and larger number of farming equipments. Possession of farmland and farm equipments were noted to considerably vary between the two groups (between soil-step-builder and non-builder households) $(\mathrm{P}<0.01$, Table 2). Supposed slope position of the farmlands investigated was discovered non-steep for more of the households approached and was found statistically variable between builders and non-builders of soil-steps $\left(\chi^{2}=9.22, \mathrm{P}<0.01\right.$, Table 3$)$. A reasonably large percentage of the households $(\approx 61 \%)$ in the soil-steps builder group perceived facing the problem of waterlodging compared to merely $43 \%$ in the non-soil-steps-builder groups $\left(\chi^{2}=4.493, \mathrm{P}<\right.$ 0.05 , Table 3).

The problem of perceived pest infestation was reported by the majority of the farmers of both groups (i.e. by $93 \%$ of the builders and $75 \%$ of the non-builders of soil-steps). The risk of pest infestation was thus found to significantly vary between the two groups $\left(\chi^{2}=6.754, \mathrm{P}<\right.$ 0.01 , Table 3). Conversely, farmers' round-trip distance from the homesteads to the farmlands 
has not explained efficient statistical deviation between the soil-steps-builder and non-builder farmers (Table 2).

Table 3.Chi-square comparison of soil-step builder and non-builder households (in \%)

\begin{tabular}{|c|c|c|c|c|}
\hline Factors & Categories & Builders $(\mathrm{N}=44)$ & Non-builders $(\mathrm{N}=157)$ & $\chi^{2}$ \\
\hline \multirow[t]{2}{*}{ Sex of the head } & M & 98 & 81 & $7.47^{\mathrm{b}}$ \\
\hline & $\mathrm{F}$ & 2 & 19 & \\
\hline \multirow[t]{2}{*}{ Performing off-farm job } & Yes & 27 & 48 & $5.88^{\mathrm{a}}$ \\
\hline & No & 73 & 52 & \\
\hline \multirow[t]{2}{*}{ Involvement in local labour groups } & Yes & 61 & 86 & $13.33^{\mathrm{b}}$ \\
\hline & No & 39 & 14 & \\
\hline \multirow[t]{2}{*}{ Tenure insecurity } & Yes & 43 & 39 & 0.27 \\
\hline & No & 57 & 61 & \\
\hline \multirow[t]{2}{*}{ Farmland slope } & Steep & 20 & 46 & $9.22^{\mathrm{b}}$ \\
\hline & Non-steep & 80 & 54 & \\
\hline \multirow[t]{2}{*}{ Waterlodging problem } & Yes & 61 & 43 & $4.493^{\mathrm{a}}$ \\
\hline & No & 39 & 57 & \\
\hline Pest infestation & Yes & 93 & 75 & $6.754^{\mathrm{b}}$ \\
\hline problem & No & 7 & 25 & \\
\hline
\end{tabular}

$\chi^{2}$ : Pearson's Chi-square ${ }^{\mathrm{a}, \mathrm{b}}$ Significance at $\leq 0.05$ and 0.01 levels.

\subsubsection{Socio-Economic and Institutional Issues}

There were statistically momentous variations between builders and non-builders of soil-steps concerning partaking in off-farm jobs and indigenous labour-sharing assemblies. The percentage of farmers engaged in off-farm employment was $27 \%$ for builders and $48 \%$ for non-builders of soil-steps $\left(\chi^{2}=5.88, \mathrm{P}<0.05\right.$, Table 3$)$. This designates that most of the farmers who built the structures do not join off-farm businesses compared to the non-builders. Roughly, $61 \%$ of the soil-step builders joined indigenous labour associations, whilst the equivalent stature for non-builders was $86 \%$ showing a meaningful statistical variation $\left(\chi^{2}\right.$ $=13.33, \mathrm{P}<0.01)$.

A sharp deviation was traced between soil-step builder and non-builder farmers pertaining to expert backing (help received from DAs). The middling contact of soil-step builders with DAs was $\approx 2$ days $\mathrm{yr}^{-1}$, while the equivalent mean contact of the non-builders was $<1$ day $\mathrm{yr}^{-1}$ ( $\mathrm{P}<0.01$, Table 2). This specifies that soil-step builders acquire more aid from DAs than the non-builders. Regularity of farmers' contact with agricultural experts enhances their exposure to new information and develops their consciousness and insights on soil erosion and the help of easily acquiring SWM technologies (Shiferaw \& Holden, 1998; Amsalu \& de Graaff, 2007). Expert help is thus an imperative issue in soil-steps building in the study villages. Conversely, no statistically important distinction was viewed in alleged land tenure insecurity between the soil-step builders and non-builders. Greater than $55 \%$ of the households from each group (from builders \& non-builders) perceived that they had a secured tenure (Table 3). 


\subsection{Binary Logistic Regression Results on Controls of Soil-Steps Building}

Numerical evaluations offered above (Tables $2 \& 3$ ) signify occurrence of major statistical disparity between builders and non-builders of soil-steps related to factors like household heads' age and gender, the number of household members and size of farmlands, the number of farm equipments owned by the households, alleged farmland slope cultivated by the households, perceived pest infestation and waterlodging problems, regularity of meeting with DAs for help, and households' interest in off-farm and indigenous labour-sharing activities. Nevertheless, educational status of the household heads', farmland distance from residence and perceptible tenure insecurity do not illustrate logical variant between soil-step builders and non-builders. These three factors denied inclusion during computations passing through the binary logistic regression model expecting that they will provide weak predictive responses. As observed in the field, farmer trainings about SWM technology adoption are frequently provided to all farmers by DAs in the studied RKAs. For that reason SWM technology adoption was observed not to widely differ between educated and non-educated farmers. Farmland distance from the homesteads was also not to widely vary among the farmers of the area. As the Federal Constitution (FDRE, 1995) provide usufruct right to all the landusers, farmers appear not to worry much about their land tenure as checked during the field work. The t-test computation (Table 2) demonstrates existence of statistically meaningful divergence between soil-step builders and non-builders connected to the rate of farmers' meeting with DAs. But, this factor was expelled from further use in the logistic regression model for it has greatly reduced the predictive power of other variables due to multicollinearity problems.

Table 4 portrays estimation results of the logit model on issues manipulating farmers' choices on building of soil-steps as SFLMTs. The Pearsons' Chi-square $\left(\chi^{2}=105.75, \mathrm{P}<.001, \mathrm{df}=10\right)$ signifies a statistically noteworthy value showing that the data are en suite to the logit model. The Hosmer-Lemeshow statistic has signified a correct replica (at $\mathrm{P}>0.05$ level). The summary table taxonomy of the studied cases (Table 4) has also revealed $\geq 87 \%$ total precision of accomplishment of evaluation (i.e. $66 \%$ for builders and $93 \%$ for non-builders of soil-steps). Except the gender of the household head, the course of influence of the rest of the issues was consistent with our initial postulates. Household heads' age, number of household members and farmland size, number of farm equipments owned and membership in indigenous labour groups revealed appreciable and positive effect on soil-steps building practices; whilst the impact of involving in off-farm jobs and the problem influx of pests (weeds, rats \& mice) found to be momentous, but negative. Gender of the household head and the risk of perceived waterlodging were hypothesized to appreciably affect soil-steps building. Furthermore, statistically important association was also observed between soil-steps builders and non-builders with these factors in the Chi-square test (Table 3). Nevertheless, the logit analysis (Table 4) confirmed a non-significant effect of these issues entailing that they are not important determinants of soil-steps building in the study villages. 
Table 4. Issues controlling soil-steps building: binary logit outputs

\begin{tabular}{|l|l|l|l|l|}
\hline Factors/issues & B & S.E. & Sig. & $\operatorname{Exp(B)}$ \\
\hline Gender of the head (1) & -1.356 & 1.284 & .291 & .258 \\
\hline Age of the head & .039 & .021 & .065 & 1.040 \\
\hline Number of household members & .382 & .156 & .015 & 1.465 \\
\hline Farmland size & 1.271 & .430 & .003 & 3.563 \\
\hline Partaking in local labour groups (1) & 2.420 & .704 & .001 & 11.241 \\
\hline Farmland slope(1) & 1.717 & .595 & .004 & 5.568 \\
\hline Problem of waterlodging (1) & -.662 & .544 & .223 & .516 \\
\hline Performing off-farm work (1) & -1.373 & .683 & .044 & .253 \\
\hline Problem of pest infestation (1) & -1.979 & .927 & .033 & .138 \\
\hline Number of farm equipments owned & 2.322 & .542 & .000 & 10.192 \\
\hline Constant & -9.386 & 1.733 & .000 & .000 \\
\hline Model- $\chi 2$ & 105.746 & & .000 & \\
\hline-2 Log likelihood ratio & 105.513 & & & \\
\hline Correctly predicted & $87.1 \%$ & & & \\
\hline Sensitivity & $65.9 \%$ & & & \\
\hline Specificity & $93.3 \%$ & & & \\
\hline Hosmer - Lemeshow statistic & & & .871 & \\
\hline Nagelkerke R Square & 0.629 & & & \\
\hline
\end{tabular}

In the logistic regression model release (Table 4), age of the household head was found feebly and positively correlating with soil-steps building (significant at $\mathrm{P}<0.10$ level). This entails that the mounting in farmers' age advances the skill of farming and the possibility of soil-step building by farmers as SFLMT. Via long years of exposure to farming, aged farmers can perceive better that soil-steps are SWM structures and can develop more soil-steps than younger farmers. The soil-steps building effort of young farmers might be constrained by smaller farmland holdings and more connection to off-farm jobs (Amsalu \& de Graaff, 2007). Amsalu \& de Graaff (2007) observed a positive effect of age on stone terrace construction in central Ethiopia. As observed from local reality, young farmers suffer from farmland shortages (e.g. see Belay et al., 2017) because the farmlands owned by their parents are too small to be shared and there are no reserve cultivable lands that can be allocated to the youth population or to the newly emerging households in many of the villages. Due to this, most young farmers cultivate contracted lands, or else, join the off-farm business. Off-farm work attracts most of the youngsters because it provides them with the chance of accessing cash money that can enable them to ease short-term problems and to satisfy daily necessities. Hence, most of them become reluctant in soil-steps building and in performing other SWM activities.

But, the above claim is in contrary to the findings of (Shiferaw \& Holden, 1998; Gebremedhin \& Swinton, 2003; Anley et al., 2007) in central, northern and western Ethiopia, respectively and Lapar \& Pandey (1999) in the Philippines which both had reported that age has a significant decreasing impact on technology adoption. Such studies argue that aged 
farmers are reluctant to new technology adoption and also lack the labour required to install SWM structures. Young farmers instead have the labour needed and receive up-to-date technological information that motivates them to apply SWM structures on their farmlands.

A unit increase in the size of household members found increasing the likelihood of farmers' building of soil-steps by about 1.5 times ( $\mathrm{P}<0.05$, Table 4 ). This specifies that having many family members is a potential for having more household labour. This outcome is well in agreement with the results of Medhin \& Kohlin (2009) for six districts in Amhara Region, Ethiopia and that of Gebremedhin \& Swinton (2003) for other six districts in Tigray, northern Ethiopia which both reported that family labour availability had a significant positive effect on adoption of SWM technologies in highland Ethiopia. Nevertheless, other studies claim that having more young children may sometimes increase the number of dependent population in a family and may not always be a potential for labour. It may rather worsen the burden of feeding the family (e.g. see Bekele \& Drake, 2003). In such circumstances, household heads may divert to off-farm business to harvest additional income to fulfill family needs. This can hinder them to apply soil-steps and other SWM technologies on their farmlands.

Ownership of large farmlands was hypothesized to definitely manipulate application of soil-steps. As anticipated, the regression model has revealed an affirmative momentous effect at $\mathrm{P}<0.01$ (Table 4). This implies that ownership of large sized farmlands encourages the likelihood of soil-steps building and it relates to many past time studies (Shiferaw \& Holden, 1998; Mbaga-Semgalawe \& Folmer; 2000; Tadesse \& Belay, 2004; Amsalu \& de Graaff, 2007; Anley et al., 2007; Medhin \& Kohlin, 2009). Having smaller farmland may not give confidence for soil-steps building. This is because it causes the loss of part of the farmland for the embankments and even makes ploughing complicated (Shiferaw \& Holden, 1998; Bekele \& Drake, 2003; Gebremedhin \& Swinton, 2003; Amsalu \& de Graaff, 2007). Gebremedhine \& Swinton (2003) suggested ownership of large plots favoured building of bunds in Tigray, northern Ethiopia. Farmers with large farmlands don't worry about the land lost for bund construction because they can grow sufficient crops from the rest of the land contrary to farmers who fear losing part of their land for it; because it can significantly impact household food supplies.

Farmland slope was another factor estimated to appreciably initiate construction of soil-steps in high-rainfall areas. The effect of this issue was also observed meaningful and positive in the logit output $(\mathrm{P}<0.01$, Table 4$)$. This signifies that a unit increase in farmland slope forces farmers to boost the probability of constructing soil-steps by about 5.6 times. Since slope is a factor for rapid soil erosion, farmers' with sloping lands are forced to frequently build soil-steps to avoid sever soil losses. Such farmers are always in touch with maintenance and improvement of the structures in the study villages and in other parts of northern Ethiopia; otherwise, they lose their precious soils. Previous studies reported that farmland slope has momentous positive relation with adoption of SWM structures (e.g. Shiferaw \& Holden, 1998; Lapar \& Pandy; 1999; Bekele \& Drake, 2003; Gebremedhine \& Swinton, 2003; Amsalu \& de Graaff, 2007; Anley et al., 2007). Gebremedhine \& Swinton (2003) for instance designated the degree of slope has amplified building of soil and stone structures in Tigray, 
northern Ethiopia. This study is thus in conformity with other similar studies in Ethiopia and elsewhere in the world.

The problem of weed and pest infestation in areas covered with stone-structures was reported to prevail in different parts of Ethiopia (e.g. Vancampenhout et al., 2006; Nyssen et al., 2007). The result in this paper is also negative and significant $(\mathrm{P}<0.05$, Table 4$)$. Pest infestation (invasion of rats \& weeds) is thus significantly deterring farmers' soil-steps building decisions in the study district. Weeds safely grow on and along the soil-steps and compete for nutrients with the crops. This retards crop growth and even causes a reduction in yields. This discourages farmers' interest of building soil-steps. Soil-steps also harbor pests (rates, cockroaches \& mice) that potentially attack crops which may cause physical injury on the growing crops and finally on yield reduction. Due to this, farmers are discouraged to build the soil-steps on their farmlands.

Possession of farm equipments is notably and positively manipulating building of soil-steps $(\mathrm{P}<0.001$, Table 4). This indicates that farmers endowed with different farm tools have more chance of building soil-steps than those who don't have farming equipments. Farm equipments (such as the iron-plough, pick axe, the hoe, spade, trowel etc.) are essential tools in agriculture and in SWM structure construction. Having such tools motivate farmers to invest on SWM structures and on other agricultural undertakings. The lack of the tools in question conversely retard farmers' soil-steps building activities and even their entire agricultural engagements. The regression result is thus tangible and conforming with the objective reality.

Taking part in off-farm job appreciably reduces the probability of building of soil-steps $(\mathrm{P}<0.05$, Table 4). It places farmers outside of farming activities and lessen the labour and time input in SWM structure installation. The outcome discovered here thus unswervingly matches to the opinions of Amsalu \& de Graaff (2007) that mentioned access to off-farm job can redirect household labour from farming to non-farming business. Off-farm work helps poor farmers' to generate cash income for immediate household needs, and hence, attract more poor people to engage in it. When poor people concentrate on off-farm business, they frequently depart from the farm venture, and then, from constructing of soil-steps. This can in turn cut the labour contribution on soil-steps application and even conceal the improvements gained from farmland management using soil-steps building. Gebremedhine \& Swinton (2003) also described that rigorous constructions of terraces were more in remote villages where off-farm prospects are restricted. In the study at hand, more farmers living nearer to Dangila town were discovered employed in charcoal and firewood making and selling business rather than working on their agricultural fields (see Belay \& Bewket, 2013a, 2015; Belay et al. 2017). Off-farm business has the power to divert farmer interests from farm to non-farm projects.

Attachment to indigenous labour associations is found notably and positively manipulating soil-steps building ( $\mathrm{P}<0.001$, Table 4$)$. Wonfel and wobera grant soil-step builders the chance to get agricultural labour when required and thus help soil-steps construction. The groups are organized by companion farmers living in the neighborhoods and closer relatives and no 


\section{Macrothink}

Environmental Management and Sustainable Development

ISSN 2164-7682 2018, Vol. 7, No. 3

more problems arise during their implementation. They also improve and strengthen the social relationship between client farmers. The finding has support from the works of Lapar \& Pandey (1999) in the Philippines, Mbaga-Semgalawe \& Folmer (2000) in Kenya and Mosseye \& Belay (2018) in Ethiopia. During data gathering activities, it was checked that farmers were working in groups on their farmlands (see Belay \& Bewket, 2013a, 2015; Belay et al., 2017). However, during FGDs and key informant interviews (Figure 2), farmers were complaining that their indigenous labour-sharing experience is disrupting by the recently introduced politically enforced 'one-into-five' ${ }^{2}$ farmer arrangement. This conforms to the recent claim reported in Mosseye \& Belay (2018) in East Godjam, Ethiopia. Hence, care has to be taken not to disrupt the inbuilt labour-sharing associations of the farmers in the study villages and everywhere in Ethiopia.

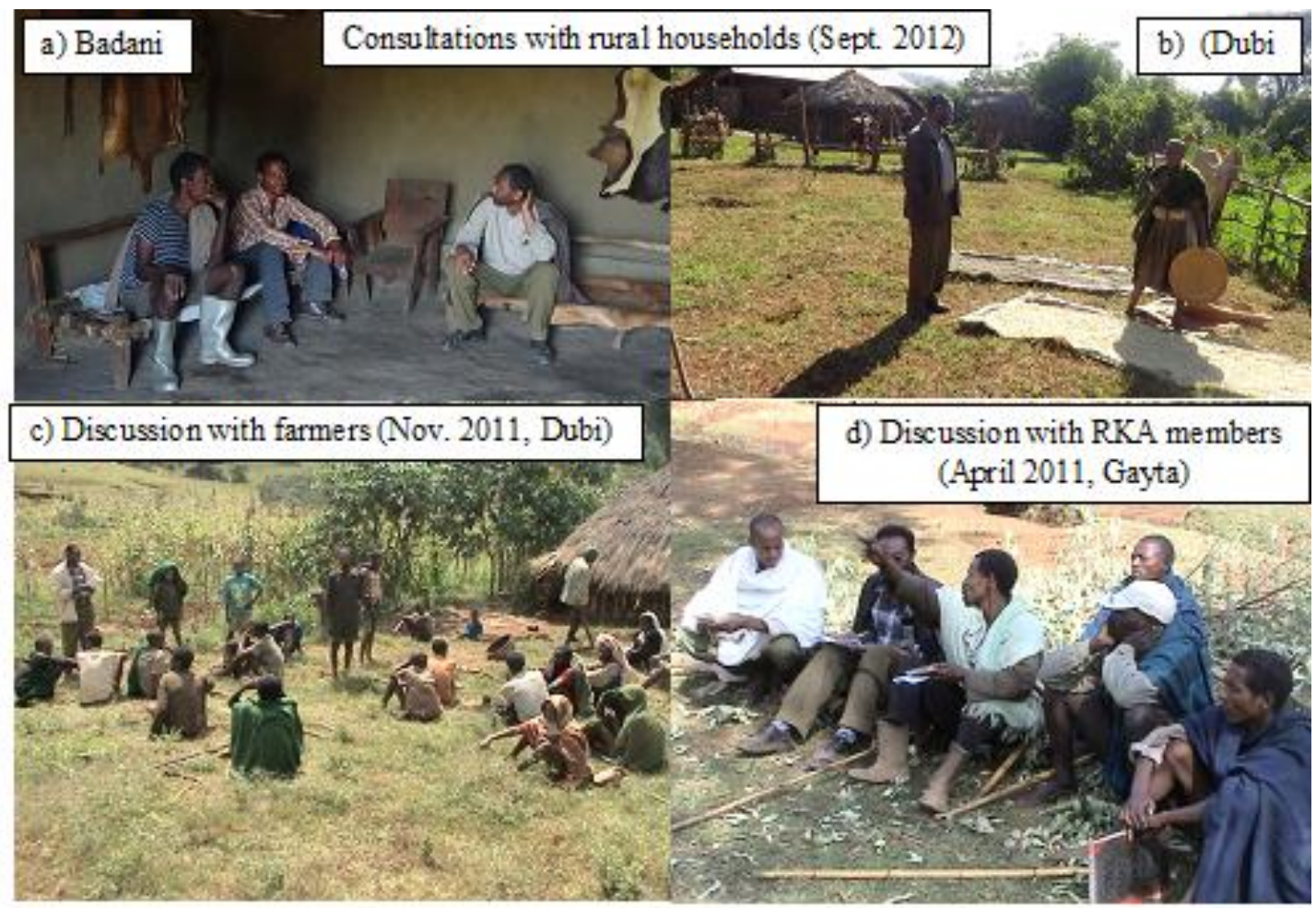

Figure 2. Discussions with different farmers and farmers' groups

Generally, the odds of farmers' soil-steps building choices are appreciably getting higher with rising in household heads' age, number of family members, farmland size, farmland slope, connecting to indigenous labour groups and number of farm equipments owned. But, the possibility of soil-steps building lessens with more involvement in off-farm jobs and pest infestation risks.

\section{Conclusion}

This paper was aimed at assessing issues controlling farmland management using soil-steps as SFLMT in a high-potential district named Dangila Woreda, in the north-western highlands

${ }^{2}$ A politically imposed labour organization sponsored by government offices 
of Ethiopia. Structured questionnaires on 201 farm households, FGDs and participatory field observations and transect tours were the sources of data. Results indicated that a number of factors are affecting farmers' building practices of the soil-steps. Household heads' age, number of household members, farmland size, and alleged farmland slope, involvement in indigenous labour-sharing associations and number of farming tools owned by the households have appreciably and positively manipulated soil-steps use practices. Conversely, the problem of pest infestation and membership in off-farm occupation were found to appreciably hamper farmers' soil-steps application practices. The results in general indicated that household endowments noticeably determine farmers' soil-steps application practices and decisions as SFLMT. This implies that households endowed with basic livelihood assets could be motivated to install soil-steps on their farmlands. Construction of soil-steps was also observed to practically assist the local farmers to conserve their soil and water resources. Future development policy and farmland management interventions ought to focus on improving farmers' resource endowments in order to strengthen their capacity to invest on SFLMTs. Farmers' participation in indigenous community labour groups has to be promoted and cares should be taken not to further reduce farmers' farmland sizes. The research was constrained with financial limitations, and hence, the study recommends that future environmental management and sustainable development research projects better be supported with sufficient financial resources.

\section{Acknowledgements}

The author is highly grateful for the farmers and DAs at the study sites for their unreserved support during the data acquisition.

\section{References}

Adenew, B., \& Abdi, F. (2006). Study on experience of land registration process in the Amhara Region. In: Proceedings of policy-makers workshop on land tenure \& land management, Oct.9, 2006, CRDA.

ALZR (Amhara Livelihood Zone Reports). (2007). Dangila Woreda, Agew Administrative Zone. Amhara Livelihood Profile, August, 2007, 8p. Available at: http://www.fegconsulting.com/feg-shared-folder/liu/Amhara/woreda-profiles/Dangila.pdf (accessed Feb., 2011).

Amsalu, A., \& de Graaff, J. (2007). Determinants of adoption \& continued use of stone terraces for soil \& water conservation in an Ethiopian highland watershed. Ecological Economics, 61, 294-302.https://doi.org/10.1016/j.ecolecon.2006.01.014

Anley ,Y., Bogale, A., \& Hiale-Gabriel, A. (2007). Adoption decision \& use intensity of soil \& water conservation measures by smallholder subsistence farmers in Dedo district, western Ethiopia. Land Degradation \& Development, 18, 289-302.https://doi.org/10.1002/ldr.775

Arndt, N., \& Menzies, M.A. (2005). The Ethiopian large igneous province. University Grenobe, France.

Bekele, W., \& Drake, L. (2003). Soil \& water conservation decision behavior of subsistence 
farmers in the eastern Highlands of Ethiopia: a case study of the Hunde-Lafto area. Ecological Economics, 46, 437-451. https://doi.org/10.1016/S0921-8009(03)00166-6

Belay, M. (2013). Local land and water management practices \& rural livelihoods in northwestern highlands of Ethiopia: Case study in Dangila Woreda. PhD Thesis, Addis Ababa University, Ethiopia.

Belay, M., Abegaz, A., \& Bewket, W. (2017). Livelihood options of landless households \& land contracts in northwest Ethiopia. Environment, Development \& Sustainability, 19(1), 141-164. https://doi.org/10.1007/s10668-015-9727-X

Belay, M., \& Bewket, W. (2012a). A participatory assessment of soil erosion \& farm management practices in northwest Ethiopia. Paper presented at the $8^{\text {th }}$ International Symposium of AgroEnviron 2012, 1-4 May 2012, Wageningen, The Netherlands, 9pp. Available at http://library.wur.nl/ojs/index.php/AE2012/article/viewFile/12449/12539

Belay, M., \& Bewket, W. (2012b). Assessment of gully erosion \& practices for its control in north-western highlands of Ethiopia. International Journal of Environmental Studies, 69(5), 714-728. http://dx.doi.org/10.1080/00207233.2012.702478

Belay, M., \& Bewket, W. (2013a). Farmers' livelihood assets \& adoption of sustainable land management practices in north-western highlands of Ethiopia. International Journal of Environmental Studies, 70(2), 284-301. http://dx.doi.org/10.1080/00207233.2013.774773

Belay, M., \& Bewket, W. (2013b). Traditional irrigation \& water management practices in highland Ethiopia: case study in Dangila Woreda. Irrigation \& Drainage, 62, 435-448. https://doi.org/10.1002/ird.1748

Belay, M., \& Bewket, W. (2015). Enhancing rural livelihoods through sustainable land \& water management in northwest Ethiopia. Geography, Environment, Sustainability, 8(2), 79-100. https://doi.org/10.24057/2071-9388-2015-8-2-79-100

Birhanu, S. (2016). Assessment of factors determine farmers adoption behavior of soil \& water conservation practice: Libo Kemkem Woreda. MA Thesis, Addis Ababa University, Ethiopia.

Chan, Y.H. (2004). Basic statistics for doctors, biostatistics 202: logistic regression analysis. Singapore Medical Journal, 45(4), 149-153.

CSA (Central Statistical Agency). (2010). The 2007 Population \& Housing Census of Ethiopia. National Statistical Summary Report. FDRE, Ethiopia.

CSA (Central Statistical Agency). (2013). Population projection of Ethiopia for all Regions at woreda level from 2014-2017. FDRE, Addis Ababa.

Desta, G., Nyssen, J., Poesen, J., Deckers, J., Mitiku, H., Govers, G., \& Moeyersons, J. (2005). Effectiveness of stone-bunds in controlling soil erosion on cropland in the Tigray highlands, northern Ethiopia. Soil Use Management, 21, 287-297.

https://doi.org/10.1111/j.1475-2743.2005.tb00401.x 
EMA (Ethiopian Metreological Agency). (2010). Data obtained \& processed through personal communication, Sept. 2010, Addis Ababa.

Erkie, M. (2016). Assessment of farmers' awareness \& adoption on soil \& water conservation practices: the case of Borebor micro watershed, Dera Woreda, Ethiopia. MA Thesis, Addis Ababa University.

FDRE (Federal Democratic Republic of Ethiopia). (1995). Constitution of the Federal Democratic Republic of Ethiopia. Addis Ababa, 40 p.

Gebremedhin, B., \& Swinton, S.M. (2003). Investment in soil conservation in northern Ethiopia: the role of land tenure security \& public programs. Agricultural Economics, 29, 69-84. https://doi.org/10.1111/j.1574-0862.2003.tb00148.x

Gebre, T., \& Weldemariam, D. (2013). Farmers' perceptions' \& participation on mechanical soil \& water conservation techniques in Kembata-Tembaro Zone: the Case of Kachabirra-Woreda, Ethiopia. International Journal of Advanced Structures \& Geotechnical Engineering, 2(4), 114-131.

Holden, S., Shiferaw, B., \& Pender, J. (2001). Market imperfections \& land productivity in the Ethiopian highlands. Environment \& Production Technology Division (EPTD), International Food Policy Research Institute (IFPRI) Discussion Paper $\mathrm{N}^{\mathrm{0}} 76$, Washington D.C., U.S.A.https://doi.org/10.1111/j.1477-9552.2001.tb00938.x

Hosmer, D.W., \& Lemeshow, S. (1989). Applied Logistic Regression. A Willey Inter-Science Publication, New York.

Hurni, H., Tato, K., \& Zeleke, G. (2005). The implications of changes in population, land use, $\&$ land management for surface runoff in the upper Nile basin area of Ethiopia. Mountain Research \& Development, 25(2), 147-154.

https://doi.org/10.1659/0276-4741(2005)025[0147:TIOCIP]2.0.CO;2

Kammer, S. (2014). Factors influencing the adoption of soil \& water conservation technologies: a case study of two farming communities in rural Ethiopia. MA Thesis, University of Washington.

Kassie, M., Pender, J., Yesuf, M., Kohlin, G., Bluffstone, R., \& Mulugeta, E. (2007). Impact of soil conservation on crop production in the northern Ethiopian highlands. International food policy research institute/ IFPRI/ Discussion Paper 00733, December 2007, Washington DC.

Kassie, M., Zikhali, P., Pender, J., \& Kohlin, G. (2010). The economics of sustainable land management practices in the Ethiopian highlands. Journal of Agricultural Economics, 61(3), 605-627. https://doi.org/10.1111/j.1477-9552.2010.00263.x

Kastner, T., \& Nonhebel, S. (2010). Changes in land requirements for food in the Philippines: a historical analysis. Land Use Policy, 27, 853-863.

https://doi.org/10.1016/j.landusepol.2009.11.004 


\section{Mll Macrothink}

Environmental Management and Sustainable Development

ISSN 2164-7682

2018, Vol. 7, No. 3

Lapar, M.L.A., \& Pandey, S. (1999). Adoption of soil conservation: the case of the Philippine uplands. Agricultural Economics, 21, 241-256.

https://doi.org/10.1016/S0169-5150(99)00028-6

Mbaga-Semgalawe, Z., \& Folmer, H. (2000). Household adoption behaviour of improved soil conservation: the case of the North Pare \& West Usambara Mountains of Tanzania. Land Use Policy, 17, 321-336. https://doi.org/10.1016/S0264-8377(00)00033-8

Medhin, H.A., \& Köhlin, G. (2009). Soil conservation \& small-scale food production in highland Ethiopia: a stochastic metafrontier approach. Working Papers in Economics No 405, University of Gothenburg, Göteborg, Seweden.

Mosseye, T., \& Belay, M. (2018). One-into-five labor-grouping for watershed management in northwest Ethiopia: farmers' acceptable participation and influencing factors. Journal of Sustainable Development in Africa (JSDA), 20(1), 172-195.

Negash, D. (2006). Adoption of improved natural resource management technologies in North-western Ethiopia: a case study in Dangila-Woreda of Amhara Region. MA Thesis, Addis Ababa University, Ethiopia.

Nyssen, J., Poesen, J., Gebremichael, D., Vancampenhout, K., D’aes, M., Yihdego, G., Govers, G., Leirs, H., Moeyersons, J., Naudts, J., Haregeweyn, N., Haile, M., \& Deckers, J. (2007). Interdisciplinary on-site evaluation of stone-bunds to control soil erosion on cropland in northern Ethiopia. Soil \& Tillage Research, 94, 151-163.

https://doi.org/10.1016/j.still.2006.07.011

Pender, J., \& Gebremedhin, B. (2007). Determinants of agricultural \& land management practices \& impacts on crop production \& household income in the highlands of Tigray, Ethiopia. Journal of African Economies, 17(3), 395-450. https://doi.org/10.1093/jae/ejm028

Rahman, M. H., \& Manprasert, S. (2006). Landlessness \& its impact on economic development: a case study on Bangladesh. Journal of Social Sciences, 2(2), 54-60. https://doi.org/10.3844/jssp.2006.54.60

Rahmato, D. (2004). Searching for tenure security? The land system \& new policy initiatives in Ethiopia. FSS Discussion Paper No.12, Forum for Social Studies (FSS), Addis Ababa, 51p.

Shiferaw, B., \& Holden, S. (1998). Resource degradation \& adoption of land conservation technologies in the Ethiopian highlands: a case study in Andit-Tid, North Shewa. Agricultural Economics, 18, 233-247. https://doi.org/10.1016/S0169-5150(98)00036-X

Sutcliffe, J. P. (1995). Soil conservation \& land tenure in highland Ethiopia. Ethiopian Journal of Development Research, 17, 63-88.

Tadesse, M., \& Belay, K. (2004). Factors influencing adoption of soil conservation measures in southern Ethiopia: the case of Gununo area. Journal of Agriculture \& Rural Development in the Tropics \& Subtropics, 105, 49-62.

Tesfay, G. (2006). Agriculture, resource management \& institutions: a socio-economic 


\section{Macrothink}

analysis of households in Tigray, Ethiopia. $\mathrm{PhD}$ Thesis, Wageningen University, the Netherlands.

Teshome, A., de Graaff, J., \& Stroosnijder, L. (2014). Evaluation of soil \& water conservation practices in the north-western Ethiopian highlands using multi-criteria analysis. Frontiers in Environmental Science. https://doi.org/10.3389/fenvs.2014.00060

Vancampenhout, K., Nyssen, J., Gebremichael, D., Deckers, J., Poesen, J., Haile, M., \& Moeyersons, J. (2006). Stone-bunds for soil conservation in the northern Ethiopian highlands: Impacts on soil fertility \& crop yield. Soil \& Tillage Research, 90, 1-15.https://doi.org/10.1016/j.still.2005.08.004

Wolka, K., \& Negash, M. (2014). Farmers' adoption of soil \& water conservation technology: a case study of the Bokole \& Toni sub-watersheds, southern Ethiopia. Journal of Science \& Development, 2(1), 35-48.

\section{Copyright Disclaimer}

Copyright for this article is retained by the author(s), with first publication rights granted to the journal.

This is an open-access article distributed under the terms and conditions of the Creative Commons Attribution license (http://creativecommons.org/licenses/by/3.0/). 